\title{
Review \\ Role of MicroRNAs in the Development and Progression of the Four Medulloblastoma Subgroups
}

\author{
Emilia Bevacqua ${ }^{1}$, Jasmin Farshchi ${ }^{2}$, Maria Victoria Niklison-Chirou ${ }^{2, *}$ and Paola Tucci ${ }^{1, *}$ \\ 1 Department of Pharmacy, Health and Nutritional Sciences, University of Calabria, 87036 Rende, Italy; \\ emilia.bevacqua@unical.it \\ 2 Centre for Therapeutic Innovation (CTI-Bath), Department of Pharmacy \& Pharmacology, University of Bath, \\ Bath BA2 7AY, UK; jkf33@bath.ac.uk \\ * Correspondence: mvnc20@bath.ac.uk (M.V.N.-C.); paola.tucci@unical.it (P.T.); \\ Tel.: +44-1225-384957 (M.V.N.-C.); +39-0984-493185 (P.T.)
}

Simple Summary: Medulloblastoma is the most common malignant paediatric brain tumour. Medulloblastoma originates in the cerebellum, a structure located at the base of the brain, affecting movement and balance in patients. Due to DNA alterations, known as mutation, some immature cells acquire new properties, transform from healthy cells into cancer cells and begin multiplying uncontrollably. During carcinogenesis, microRNAs (miRNAs or miRs) play important roles in medulloblastoma, helping cells to proliferate (oncomiRs) or inhibiting cell proliferation and promoting cell differentiation (tumour suppressor miRs). Therefore, in this review, we summarize the role of miRNAs in the four medulloblastoma subgroups and the importance of these non-coding RNAs to provide potential therapeutic applications.

check for updates

Citation: Bevacqua, E.; Farshchi, J.; Niklison-Chirou, M.V.; Tucci, P. Role of MicroRNAs in the Development and Progression of the Four Medulloblastoma Subgroups. Cancers 2021, 13, 6323. https://doi.org/ $10.3390 /$ cancers 13246323

Academic Editor: Adam E. Frampton

Received: 4 December 2021

Accepted: 14 December 2021

Published: 16 December 2021

Publisher's Note: MDPI stays neutral with regard to jurisdictional claims in published maps and institutional affiliations.

Copyright: (c) 2021 by the authors. Licensee MDPI, Basel, Switzerland. This article is an open access article distributed under the terms and conditions of the Creative Commons Attribution (CC BY) license (https:/ / creativecommons.org/licenses/by/ $4.0 /)$.

\begin{abstract}
Medulloblastoma is the most frequent malignant brain tumour in children. Medulloblastoma originate during the embryonic stage. They are located in the cerebellum, which is the area of the central nervous system (CNS) responsible for controlling equilibrium and coordination of movements. In 2012, medulloblastoma were divided into four subgroups based on a genome-wide analysis of RNA expression. These subgroups are named Wingless, Sonic Hedgehog, Group 3 and Group 4. Each subgroup has a different cell of origin, prognosis, and response to therapies. Wingless and Sonic Hedgehog medulloblastoma are so named based on the main mutation originating these tumours. Group 3 and Group 4 have generic names because we do not know the key mutation driving these tumours. Gene expression at the post-transcriptional level is regulated by a group of small single-stranded non-coding RNAs. These microRNA (miRNAs or miRs) play a central role in several cellular functions such as cell differentiation and, therefore, any malfunction in this regulatory system leads to a variety of disorders such as cancer. The role of miRNAs in medulloblastoma is still a topic of intense clinical research; previous studies have mostly concentrated on the clinical entity of the single disease rather than in the four molecular subgroups. In this review, we summarize the latest discoveries on miRNAs in the four medulloblastoma subgroups.
\end{abstract}

Keywords: miRNA; medulloblastoma; brain tumour; subgroups; stem cells

\section{Introduction}

Medulloblastoma (MB) is the most common primary malignant solid tumour of the central nervous system (CNS) in children and originates in a region of the brain known as cerebellum [1]. Embryonic tumours of the CNS account for approximately $4 \%$ of childhood cancers [2]. In Italy, according to AIRTUM (Italian Association of Cancer Registries) data, about 7 children per year out of a million are affected by this type of disease [3]. The incidence is slightly higher among males than females and is higher in younger children. Moreover, children with certain genetic diseases, such as Turcot syndrome, Gorlin syndrome, Li-Fraumeni syndrome, are at greater risk of developing medulloblastoma $[4,5]$. 
The symptoms related to a medulloblastoma depend on the tumour's size and location [6]. The most common symptoms of medulloblastoma are headache, nausea and vomiting, progressive instability in walking, problems with coordination of the hands, arms, legs or feet, difficulty synchronizing eye movements, and changes in modulation of the voice [7].

Medulloblastoma is caused by different gene mutations, which can transform a healthy cell into a tumour cell [8]. It has been shown, following the discovery of miRNAs, that gene regulation can be altered at different levels, thus leading to tumour formation [9].

In 2005, it was reported for the first time that miRNAs play a central role in brain tumour development [10]. Since then, several studies have been performed in order to shed light on the role of miRNAs in brain tumours such as medulloblastoma in both paediatric and adult populations. Importantly, by using next-generation sequencing in a large cohort of medulloblastoma patients, common driver mutations have been revealed in each medulloblastoma subgroup [11]. However, the role of miRNAs in the framework of the different subgroups is still limited, since most of the studies have concentrated on the clinical entity of the single disease.

In this review, we highlight the major findings on the role of the miRNAs in the development and progression of medulloblastoma, their potential as biomarkers for cancer diagnosis, prognosis and therapeutic applications, with a particular focus on the regulation of the miRNAs in the four different medulloblastoma subgroups.

\section{Medulloblastoma's Classification}

Medulloblastoma can be classified into different subgroups, which are distinguished based on how they present under the microscope (histological classification) or genetic alterations.

According to the World Health Organization (WHO), histological classification distinguishes four forms [12]:

- Classic, that is the most common subtype;

- Desmoplastic/nodular;

- Extensive nodularity, that is predominantly in infants;

- Anaplastic/large cell.

The classic forms, desmoplastic and with extensive nodularity, generally have a more favourable prognosis, while the anaplastic large cell form is the more aggressive [1] and displays high levels of atypia.

A more recent classification, based on genomics data, also divides medulloblastomas into four subgroups known as Wingless (WNT) and Sonic Hedgehog (SHH), which are better described and Group 3 (Grp3) and Group 4 (Grp4) less characterized. These new medulloblastoma entities are based on the presence of a specific gene mutation or amplification that causes cell proliferation $[13,14]$.

\section{Diagnosis, Prognosis and Therapy}

The diagnosis of medulloblastoma is made with imaging techniques such as computed tomography (CT) scan and, subsequently, magnetic resonance imaging (MRI) within one to three months from the appearance of the first symptoms, since medulloblastoma is a rapidly growing tumour [15]. Given the possibility of metastasis to other regions of the CNS, it is always essential to obtain images of both the brain and the spinal cord [13]. A cerebrospinal fluid sampling by lumbar puncture allows to exclude the presence of neoplastic cells at this level. Confirmation by histological examination is obtained after surgery to remove the tumour [16]. Dissemination outside the CNS is very rare.

The evolution of the disease (prognosis) and response to therapies are mainly linked to the medulloblastoma subgroup and to the presence of metastasis at diagnosis, although generally these tumours respond to therapies much better than other neoplasms of embryonic origin. The presence of metastasis in medulloblastoma is a poor prognostic factor. The treatment options for patients with metastases are limited. Unfortunately, it is not 
uncommon, even if the therapies have worked, for the tumour to reoccur after some time (relapse). In this case, the treatments are generally ineffective [17]. The 5-year survival from diagnosis is around $60-70 \%$ [6].

The therapy of choice for medulloblastoma is surgical removal of the tumour followed by chemotherapy and radiotherapy [18]. Ideally, the operation should completely remove all cancer cells, but it may be impractical if the tumour is in an inaccessible area or if there is a risk of damaging an area of vital importance or compromising the physical and cognitive functions of the patient [19]. Complementary therapy to surgery is direct radiotherapy to the head and spine (craniospinal radiotherapy) [20]. Over the decades, radiotherapy techniques and doses, both on the entire CNS and on the site of origin of the disease, have evolved and been modulated in order to make the treatment more effective and less harmful. The introduction of chemotherapy also contributed to this, which, depending on the initial situation, can be used after radiotherapy or before it. In special cases, in relation to the patient's age, histological type and genetic subgroup, it is possible to reduce the total doses of radiotherapy or even omit it. It is important that the treatment plan also includes a rehabilitation path, which improves both the response to treatment and the quality of life of the young patient [21]. Finally, as in all paediatric diseases, an adequate and prolonged follow-up is essential in order to offer the best possible quality of life to the patient treated for cancer.

\section{3. miRNAs}

MiRNAs are small, non-coding regions in RNAs of around 22 nucleotides (nt) [22], that induce translational repression or degradation of a target mRNA upon imperfect base pairing to its $3^{\prime}$ untranslated region ( $\left.3^{\prime} \mathrm{UTR}\right)$.

Initially, the biogenesis of miRNAs occurs in the nucleus with the transcription of the miR by an enzyme called RNA-polymerase II. The miRNAs derive from a primary precursor (pri-miRNA) of 100-1000 nt. The formation of mature miRNA occurs in three phases, the first still in the nucleus, the other two in the cytosol: (i) Cropping: cutting performed by RNAse III enzyme Drosha capable of cutting the region flanking the primiRNA. Other proteins that confer specificity are associated with the Drosha enzyme (ex. DGCR8). Following the cropping and the action of Drosha, the pre-miRNA composed of $80 \mathrm{nt}$ is released, with a stem-loop structure, it has a $5^{\prime} \mathrm{P}$ and a $3^{\prime} \mathrm{OH}$ and $2-3 \mathrm{nt}$ at the $3^{\prime} \mathrm{OH}$ end single helix protruding; (ii) Export: the pre-miRNA is transported into the cytoplasm by Exportin5/RanGTP, a heterodimer is formed which passes through the nuclear pores; (iii) Dicing: the pre-miRNA undergoes a further cleavage by another RNAse III enzyme Dicer which, together with its partner TRBP (HIV-1 TAR RNA RBP), process the pre-miRNA in a miR duplex of 18-22 nt. [23-25].

Then, while the mature miRNA duplex binds to AGO proteins forming RNA-induced silencing complex (RISC), in some cases, one of the two strands of the duplex is degraded, while the other accumulates as mature miRNA. From the duplex produced by Dicer, the miRNA enters in the protein effector complex RISC, with the presence of proteins belonging to the Argonauts family (AGO), which mediates the degradation or inhibition of mRNA translation of the target gene. In particular, the AGO2 protein, together with other proteins, forms the RISC multiprotein complex with endonuclease activity capable of specifically degrading a target RNA containing sequences complementary to the guide sequence of the miRNA. Eight members of the AGO family have been identified in the man. However, only the enzymatic function of the AGO2 protein is well known [26].

Some miRNAs appear imperfectly with the $3^{\prime}$ UTR of the target mRNA and inhibit translation; other miRNAs show a precise complementarity to their target and lead to mRNA degradation. The biogenesis of miRNA and the mechanism by which they silence gene expression are represented in Figure 1. 


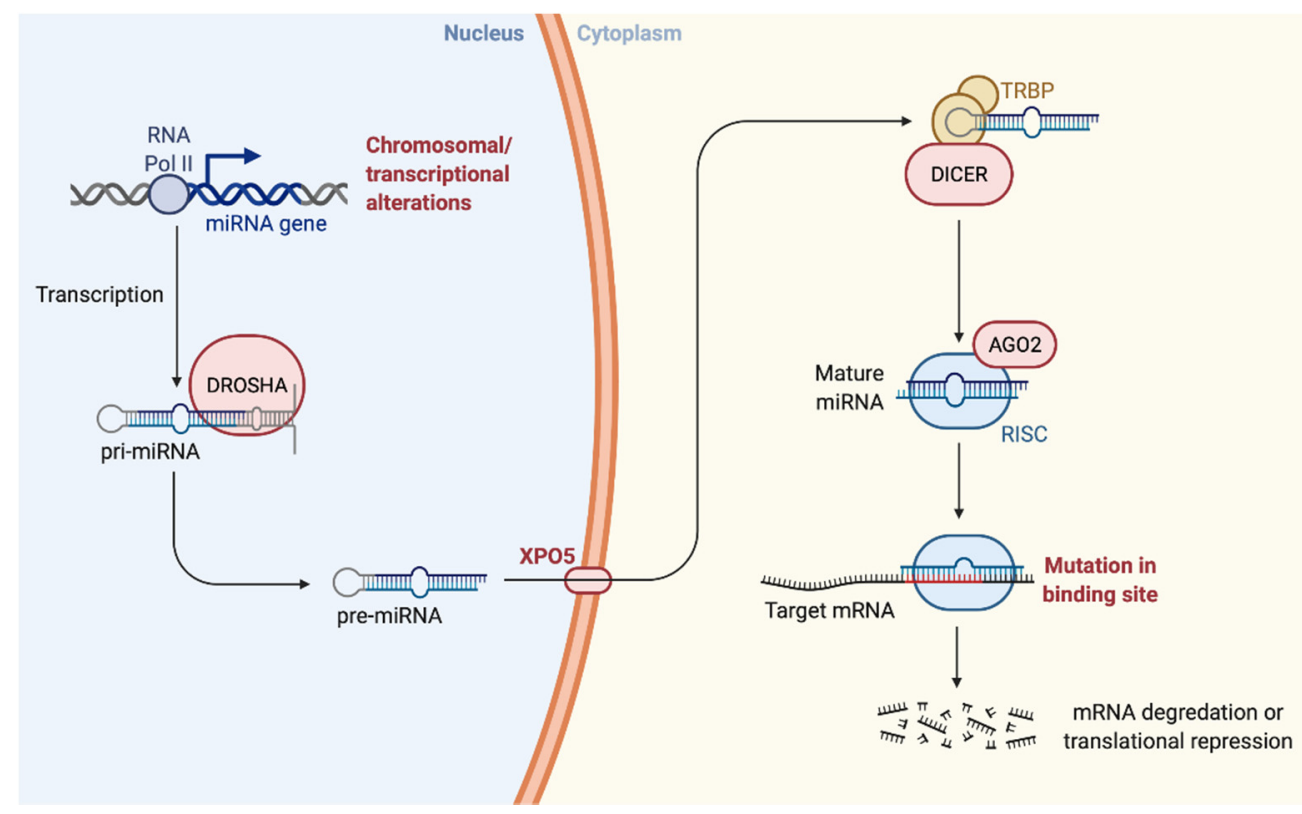

Figure 1. Biogenesis of the microRNA. "Created with BioRender.com".

MiRNAs are essential for the normal development of all tissues, as they control the most important biological processes such as cell growth, differentiation, metabolism and apoptosis [24]. For example, in Drosophila miR-14 prevents cell death and is required for normal lipid metabolism; miR-125b and miR let-7 control cell proliferation; miR-181 is involved in the development of the hematopoietic lineage of B lymphocytes [25]. MiR-15a and miR-16-1 promote the survival of immune B cells; miR-375 is involved in insulin secretion and miR-143 promotes the development of adipocytes $[25,27]$.

\subsection{Role of miRNAs in Neuronal Development}

Nowadays, it is well accepted that miRNAs play a central role in several physiological processes. In particular, miRNA roles have been described during CNS developmentrelated processes, response to ambient demands and injuries, stress or mental disorders. miRNAs are versatile regulators of gene expression, and they emerge as key players in numerous pathophysiological conditions, including CNS development, adaption and disease. Indeed, the significance of miRNA in development was confirmed by the fact that the loss of Dicer function causes lethal aberrations. It is estimated that over $60 \%$ of documented miRNAs are detected in the adult brain, and many of these change their expression as the embryonic brain develops and matures [28]. Recent data have also shown that miRNAs are expressed in the vertebrate nervous system and that their expression is modulated by synaptic activity, essential for learning and memory formation [27]. Altered morphology and neuronal development can result from errors in post-transcriptional processes that are closely regulated by miRNAs. Specific miRNAs are expressed in different compartments of the neural axis, and it has been hypothesized that miRNA pathways play a dominant role in inducing neuronal fate and synaptic plasticity [29]. Since early brain development and later synaptic plasticity are also regulated by miRNAs, it has been hypothesized that neurological disorders are influenced by their expression or alteration [30,31]. Neuronal differentiation, excitability and function are controlled by neuronal-specific miRNAs. For example, the transition from neuronal precursor to mature neurons is caused by the increase in miR-9 and miR-124 and therefore in the differentiation of embryonic stem cells. Scientists have displayed that miR-9 determines an inhibition of neurogenesis along the anterior-posterior axis [32], while miR-124 represses neuron-specific splicing patterns [33]. Neuronal differentiation and neurite growth, on the other hand, is modulated by miR-7 and miR-214 (as compared to miR-1,-16 and -133a) [27]. Neurodegenerative diseases such 
as Parkinson's, Alzheimer's or cancer also involve a reduction in the function of specific miRNAs $[34,35]$.

\subsection{Role of miRNAs in Cancer}

The miRNAs are recognized to play a central role in development as well as in cell growth and proliferation, in differentiation, apoptosis, cell cycle, and metabolism controlling the expression levels of many genes [36]. Consequently, the alterations in the expression of these small RNAs play a key role in a wide variety of human diseases, including cancer. The first evidence of the involvement of a miRNA in cancer was demonstrated by Calin et al., in 2002 [37]. Since then, many studies have reported miRNA dysregulation in various human diseases [38]. About $50 \%$ of human miRNAs annotated are located in fragile sites of the genome associated with cancer and, moreover, they have been found differentially expressed between tumour cells and normal cells. Some miRNAs are downregulated while others are overexpressed in cancer, suggesting that miRNAs can act as tumour suppressor genes or oncogenes, respectively [39]. The epigenetic regulation of miRNAs, the hypomethylation of DNA, the increase in DNA methylation and the disruption of histone modification patterns in the miRNA locus, are greater than the genes that encode proteins. The miRNA genes can be silenced in some types of human tumours by aberrant hypermethylation of $\mathrm{CPG}$ Island that surrounds it, or is close to the miRNA of histone modification genes [40]. DNA hypermethylation in breast, lung and colon carcinomas was favoured by a decrease in the expression of miR-9-1 [41], miR-124a and miR-145-5p [42].

The aberrant expression of miRNA may be due to mutations in its sequence that cause a reduction in the expression of mature miRNA or an altered regulation of the target gene [43]. The activity of these small regulatory elements can also be altered by genomic rearrangements such as deletions or duplications of the genomic region in which the miRNA is located, or translocations that relocate the miRNA under the control of a new promoter.

The conclusive effects may be an increase in miRNA expression with a consequent decrease in expression of the target gene or a decrease in miR expression with a consequent overexpression of the target (Figure 2).

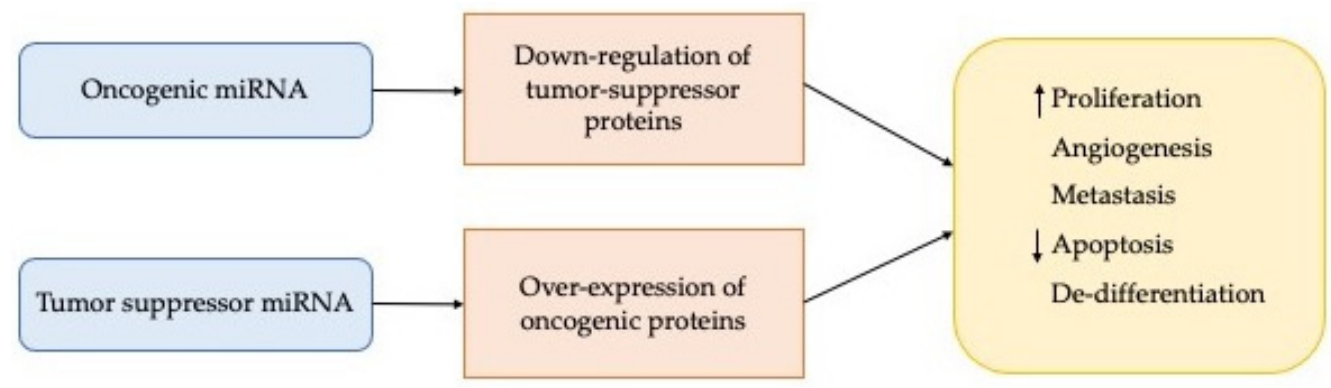

Figure 2. Main effects of deregulation of the miRNA expression.

Despite the huge amount of miRNAs identified to date, their role in tumour processes is not entirely clear. However, the presence of miRNA circulating in the blood of cancer patients has increased the possibility that they could serve as new diagnostic and prognostic biomarkers, either alone or in combination with other well-stablished biomarkers [44].

In fact, some miRNAs are specifically more expressed only in one type of tumour, managing to also characterize malignancy $[45,46]$. Another reason for the choice of miRNAs as tumour biomarkers is to be found in the non-invasiveness of the analysis. In fact, miRNAs have been isolated from serum, plasma, saliva, urine and other cell fluids [46]. Several studies have shown that in these compartments the expression of miRNAs is correlated with specific tumours.

An early study [47] was concerned with identifying a tumour suppressor on chromosome 13q14, which was involved in chronic lymphocytic leukaemia (CLL), the most common form of leukaemia. They showed that the 13q14 locus does not contain genes 
encoding tumour suppressor proteins, but two microRNA genes, miR-15a and miR16-a, are expressed in the same polycistronic RNA. This result shows that the deletion of chromosome 13q14 would cause the loss of these two miRNAs, and therefore it is evident that these miRNAs are involved in the pathogenesis of human cancer.

Moreover, the discovery that miRNAs play a vital role in different types of tumour and since they have the advantage of being able to act both as oncogenes and as tumour suppressors they are still considered potential tumour therapeutic targets [48]. Carcinogenesis is favoured by oncogenic miRNAs, which are then over-expressed; on the contrary, the tumour suppressor action is due to a decrease in particular miRNAs (Figure 2). In light of the above, the antagomirs lead to a downregulation of the oncomirs. The concept of "miR replacement therapy" was thus introduced thanks to the observation of the reduction of the pathology following the action of suppressive miRNAs, with the aim of increasing the amount of reduced miRNAs and bringing them to normal values. This approach has great potential to be a more practical strategy than silencing individual genes by siRNAs and represents one of the major commercial areas of interest in today's biotechnology market.

\section{4. miRNAs Involvement in the Different Subgroups of Medulloblastoma}

In 2012, it was agreed during an international meeting that medulloblastoma has four distinctive molecular subgroups named: Wingless (WNT-good prognosis), Sonic Hedgehog (SHH-intermedia prognosis), Group 3 (Grp3-bad prognosis) and Group 4 (Grp4-intermedia prognosis) [49]. WNT and SHH are named because these tumours have mutations in the WNT and SHH signalling pathways, respectively. To date, no clear underlying signalling pathways associated with Grp3 and Grp4 have been identified. Emerging evidence suggests that each group may require specific therapeutic strategies [50].

\subsection{Wingless (WNT) Subgroup}

WNT represent $10 \%$ of all medulloblastomas cases [51]. It occurs typically in adolescents and children over the age of 4 and is associated with excellent prognosis (>95\% survival at 5 years in paediatric patients) [52]. WNT primary tumours are driven by a mutation in the CTNNB1 gene, which encodes b-catenin [53]. Mutation in this gene causes a constitutively upregulation of gene expression that promotes tumour growth and proliferation. Patients with WNT subgroups harbour TP53 mutations. In fact, WNT with p53 mutation have an excellent prognosis, suggesting that TP53-inactivating mutations on their own do not confer a poor survival [54]. Interestingly, the robust therapeutic response is attributed to an aberrant fenestrated vascular endothelium in the tumour. The fenestrated endothelial surface allows the accumulation of high levels of chemotherapeutic drugs in the tumour, thereby enhancing treatment [55]. However, children with a WNT diagnosis, are predisposed to primary tumour haemorrhage which can lead to severe complications [56]. Due to excellent prognosis of the WNT subgroup, a new clinical trial has been recently created to evaluate the reduction in chemotherapy and radiotherapy doses [57]. It was reported that miR-383, miR-206, miR-183, miR-128a/b and miR-133b are downregulated in this medulloblastoma subgroup [58] and the level expression of miR-449 is also completely different from other MB subtypes. miR-449 is down-regulated by aberrant DNA methylation in the WNT Group [59]. It was found that miR-148a expression is regulated by the NRP1 target. NRP1 target is involved in several pathways promoting tumour growth, invasion and metastasis. The downregulation of this target is due to the tumour suppressive effect of miR-148a expression and the subsequent reduction in tumorigenicity [60].

\subsection{Sonic Hedgehog (SHH) Subgroup}

$\mathrm{SHH}$ represents approximately $30 \%$ of $\mathrm{MB}$ cases and appears typically in infants and adults, accounting for two thirds of cases in these age groups [61]. The prognosis of this subgroup varies based on age and metastatic status and molecular mutations. It has recently been shown that p53, a tumour suppressor protein, is a prognostic marker for $\mathrm{SHH}$ MB patients. In fact, patients with mutations of TP53 gene have a worse outcome of the 
disease than those with wild-type TP53 [62]. The altered SHH signalling pathway is mainly caused by germline or somatic mutation or copy number alterations in the SHH signalling pathway, which leads to tumour development and proliferation. The most common mutations are protein patched homolog (PTCH) inactivating mutation and smoothened homolog (SMO) activating mutation [63]. In fact, infant (35\%) and children (45\%) have mutations in the downstream SMO pathway, which makes tumours intrinsically resistant to SMO inhibitors [63]. Therefore, the recent approaches to modulate SHH signalling is focused on SMO inhibition and the mechanisms of acquired resistance in downstream SMO pathway. The metastasis of $\mathrm{SHH}$ subgroup happens at the same site of primary tumour. In a recent study, cancer stem cells (CSCs) have been isolated from SHH and expression level of epithelial to mesenchymal transition (EMT) transcript and microRNAs was compared with cerebellar NSCs [5]. Vegfa and its receptor Nrp2 are two molecules up regulated in SHH CSCs and involved in EMT [64]. If these two molecules are inhibited there will be a reduction of the cell viability and the ability of CSCs to self-renew. This mechanism leads to the modulation of two markers involved in EMT, therefore we will see the increase in the epithelial marker (E-Cadherin) and, on the other hand, a reduction of the mesenchymal one (Vimentin). The miRNA identified as an inhibitor of Vegfa and Nrp2 is miR-466-3p [64].

Furthermore, CSCs identified in SHH-MB are controlled by the Sonic Hedgehog/Gli (Hh/Gli) is an aberrant signalling pathway that control CSCs identified in SHH medulloblastoma, regulated by miR-326. More precisely, the downregulation of miR-326 is characteristic of these tumours, therefore an overexpression of miR-326 leads to the inhibition of that signalling pathway [65].

More recently, in vivo and in vitro studies have displayed that SHH MB cells showed a reduction in tumour growth by silencing miR-17/20 and miR-19a/b [66]. Furthermore, miR-17-92 cluster is involved in SHH tumours. Within this cluster belong miR-18a, -19a, $-20 a,-21,-25$ and $-106 b$ [67]. Several studies have evaluated the effect of miR-10b on the growth and proliferation of medulloblastoma through the transcriptional induction of BCL2, a tumour promoter [68]. Potent inhibitors of BCL-2, such as ABT-737 and ABT-199, were evaluated on the expression of miR-10b [69]. Powerful BCL-2 inhibitors significantly inhibit the expression of miR-10b in a dose-dependent manner. This miRNA is strongly associated with tumours, as it plays a crucial role in cell proliferation and survival, moreover miR-10b is not expressed in a normal brain. Several studies suggest that miR-10b is an oncomiR that regulates cell growth and survival of this medulloblastoma subgroup by controlling BCL2 levels [68].

\subsection{Group 3 (Grp3) Subgroup}

Grp3-MB is the most aggressive paediatric brain tumour and occurs mostly in infants and young children. This subgroup is (40-45\%) metastasis at diagnosis and is resistant to combinations of surgery, radiotherapy and chemotherapy [53]. Therefore, it is associated with poor prognosis and the worst survival outcome of any subgroup (under $60 \%$ at 5 years). Unlike WNT and SHH subgroups, there is no distinctive altered signalling pathway identified for Grp3. However, amplification of MYC (17\%) and hyper activation of the GFI1B oncogene (15-20\%) are mostly observed. TP53 mutations were almost never observed in patients with Grp3, in which isochromosome 17q is a common aberration [54]. It was showed that miR-183-96-182 cluster are up-regulated in Group 3 of medulloblastoma. In particular, the expression of the miR-183 cluster in cells was associated with the dysfunction of the DNA damage repair and with the pathways associated with migration, EMT and metastasis [70]. Metastasis of Grp3 happens at a different site of the primary tumour. It was reported that, in medulloblastoma cell lines DAOY, D425 and D283 belonging, respectively, to the SHH subgroup and Grp3, there is an under-expression of miR-30a family [71]. Group 3 and 4 are associated with the highest mortality compared to other MB subgroups. Group 3 of MB displayed a deregulation of miR-1253 expression [72]. They showed that the restoration of miR-1253 expression is linked with a reduction in tumour cell malignancy, which also leads to the activation of apoptotic pathways. A recent study highlighted the 
expression of seven miRNAs belonging to the miR-30 family in the 4 subtypes of medulloblastoma. These miRNAs are significantly downregulated $(p<0.00001)$ compared to normal cerebellar tissues [71]. The inhibition of the clonogenic potential, proliferation and tumorigenicity of different cell lines of medulloblastoma is notable after the recovery of miR-30a through the lentiviral vector. MiR-30a is known to mediate autophagy through the Beclin1 target. Therefore, it has been shown that the expression of miR-30a leads to a down-regulation of genes implicated in autophagy, such as Beclin1, with consequent inhibition in medulloblastoma cells. Autophagy is a process that allows our cells to recycle and renew themselves. The cells then destroy their components that have become useless and carry them out of the membrane, playing a fundamental role in our defences. This process leads, on the one hand, to cleaning the cell, on the other hand it allows the cell to sustain itself in difficult situations [73]. Additionally, in the medulloblastoma, low levels of miR-4521 leads to an up-regulation of the transcription factor forkhead box M1 (FOXM1). FOXM1 regulates the expression of various genes involved in tumour progression [74]. The Grp3 is the only one with a statistically significant difference in miR-4521 expression reduction compared with the healthy control tissue, while in SHH subgroup there are no particular differences.

\subsection{Group 4 (Grp4) Subgroup}

Grp4 accounts for $35-40 \%$ of all medulloblastoma diagnosis and occurs typically in children and adolescence [75]. This subgroup is (35-40\%) metastasis at diagnosis, although the survival outcomes are intermediate, and the recurrences mostly occur late. Grp4 share similar gen amplifications as Grp3 as mentioned above and have not an identified signalling pathway [76]. At the same time, Orthodenticle homeobox 2 (OXT2) amplification and the gain of isochromosome 17q is also seen in Grp4 and Grp3 [77]. Similar to Grp3, TP53 mutations has never been observed in Grp4 and the metastasis is at a different site of the primary tumour. Compared to the other subgroups, Group 4 has a lower expression of miR-181a-2-3p, which is reported to be involved in the formation of glioma acting as tumour suppressors [78,79]. While a high expression was observed for miR-187-3p and could be linked to a poor prognosis of patients with Group 4 MB [80]. Additionally, miR206 was down-regulated in all four medulloblastoma subgroups. Indeed, miR-206 acts on OTX2, an oncogene which is involved in Grp4 pathogenesis. Overexpression of OTX2 leads to growth and proliferation of medulloblastoma. Therefore, under-expression of miR-206 contributed to the upregulation of OTX2 expression and enhanced growth of G4 cell lines [58]. A recent study showed that the tumour-suppressive let-7 miRNA family is downregulated by gene LIN28B and the expression of these miRNAs is significantly lower in Group 3 and 4 compared with WNT and SHH MB [81]. miR-4521 is located on chromosome 17p13.1. They show that a loss of chromosome 17p is closely associated with Grp3 and Grp4-subgroups [74].

\section{Role of miRNAs in Medulloblastoma}

The most studied tumours at the level of miRNA deregulation are breast, prostate, colon and leukaemia's; little has been studied regarding the alterations of miRNAs in medulloblastoma. Ferretti et al. conducted one of the first studies on the expression profile of miRNAs in medulloblastoma [82]. A total of 250 miRNAs were screened in 31 primary medulloblastoma specimens and 34 miRNAs differentially expressed between SHH-MB versus WNT-MB, Grp3-MB and Grp4-MB were identified. Additionally, three down-regulated miRNAs were identified in SHH-MB, miR-125b, miR-326 and miR-324-5p. Interestingly, these three miRNAs are known to target Smoothened (SMO), an activator of the Hedgehog signalling pathway [82]. In addition, miR-324-5p also targets Gli1, a committed transcription factor for the Hedgehog signalling pathway. Additionally, it was suggested that a possible genetic anomaly is the cause of the loss of function of miRNA324-5p in SHH-MB [83]. In fact, this miRNA is contained in a gene region of chromosome $17 \mathrm{p}$, which is one of the most frequent deletions in medulloblastoma. In addition to the 
miRNA, this chromosomal region also contains the tumour suppressors p53 and HIC1 but also the antagonist of the REN signal pathway [84].

In a different study conducted by Ferretti et al., 248 miRNAs were analysed in medulloblastoma samples, and 248 miRNAs differentially expressed between tumours and normal adult and foetal cerebellar tissue were detected [85]. In this analysis, two miRNAs, miR-9 and miR-125a, were identified as downregulated in medulloblastoma and target the truncated isoform of the neurotropin receptor (TrkC). By comparing medulloblastoma and normal foetal cerebellum it was possible to identify a cluster of upregulated miRNAs in SHH-MB versus non-SHH medulloblastomas known as cluster 17-92 [67]. This miRNA cluster is induced by $\mathrm{N}$-myc in the neuronal cerebellar precursors treated with Sonic Hedgehog; this evidence indicates that the 17-92 miRNAs cluster is a positive effector of the proliferative effects of the Hedgehog signalling pathway.

Additionally, Uziel et al. [86], using medulloblastoma cells from Ink4c ${ }^{-/-}$; Ptch1 ${ }^{+/-}$and Ink4 $\mathrm{c}^{-/-}$; $\mathrm{p} 53^{-/-}$genetically modified mice versus mature mice, identified many deregulated miRNAs: 26 upregulated and 24 downregulated. In particular, 9 of these 26 upregulated miRNAs were demonstrated to encode cluster 17-92. To this cluster belong miR-92, miR-19a and miR-20 that are upregulated in the Hedgehog subgroup of medulloblastoma. Thus, demonstrating the close correlation between cluster 17-92 and the Hedgehog signalling pathway [86].

Two miRNAs (miR-30b and miR-30d) were identified located in a commonly amplified region in medulloblastoma, adjacent to the MYC locus on chromosome 8q24. Such miRNAs were found upregulated in a subgroup of primary medulloblastoma [87].

Cluster 183-96-182 was found upregulated in controlled non-Hedgehog medulloblastoma and, in particular, miR-182 was significantly upregulated in metastatic medulloblastoma [88]. It was later shown that this cluster is involved in the suppression of genes associated with apoptosis and the regulation of the PI3K/AKT/mTOR axis [89].

Venkataraman et al. showed that several miRNAs that are downregulated in medulloblastoma have an active role in normal brain development. In particular, miR-128a has been shown to be an antagonist of the Bmi1 oncogene [90].

Many miRNAs can influence tumorigenesis through their tumour suppressor action, such as miR-34a which if overexpressed in medulloblastoma cells and induces apoptosis and restores sensitivity to chemotherapy [89], or miR-199-5p that by its target HES1 regulate the cancer stem cells [91].

Therefore, miRNAs can potentially regulate several pathways involved in the insurgence and progression of the medulloblastoma, acting as both oncogene and tumour suppressor (summarized in Table 1).

Table 1. Summary of deregulated miRNAs involved in the pathogenesis and progression of the four MB subgroups.

\begin{tabular}{|c|c|c|c|c|c|}
\hline \multicolumn{6}{|c|}{ SUBGROUP 1: WINGLESS } \\
\hline $\begin{array}{l}\text { miRNAs as } \\
\text { Oncogenes }\end{array}$ & Cellular Function & Ref. & $\begin{array}{l}\text { miRNAs as } \\
\text { Suppressors }\end{array}$ & $\begin{array}{l}\text { Cellular } \\
\text { Function }\end{array}$ & Ref. \\
\hline $\begin{array}{l}\text { miR 30b, } \\
\text { miR-30d }\end{array}$ & $\mathrm{N} / \mathrm{A}$ & [87] & $\operatorname{miR}-9$ & $\begin{array}{l}\text { Antiproliferation } \\
\text { Differentiation } \\
\text { Pro-apoptosis }\end{array}$ & {$[85,92]$} \\
\hline miR-193a & $\begin{array}{l}\text { Metastasis } \\
\text { Proliferation }\end{array}$ & [93] & $\operatorname{miR}-148 a$ & $\begin{array}{l}\text { Antiproliferation } \\
\text { Invasion } \\
\text { Reduces } \\
\text { tumorigenicity }\end{array}$ & {$[60,85,93]$} \\
\hline miR-224 & $\begin{array}{c}\text { Proliferation } \\
\text { Radiation-sensitivity. } \\
\text { Anchorage-independent } \\
\text { growth }\end{array}$ & {$[93,94]$} & & & \\
\hline
\end{tabular}


Table 1. Cont.

\begin{tabular}{|c|c|c|c|c|c|}
\hline \multicolumn{6}{|c|}{ SUBGROUP 2: SONIC HEDGEHOG } \\
\hline $\begin{array}{c}\text { miRNAs } \\
\text { as Oncogenes }\end{array}$ & Cellular Function & Ref. & $\begin{array}{l}\text { miRNAs } \\
\text { as Suppressors }\end{array}$ & Cellular Function & Ref. \\
\hline miR-17/92 & N-Myc target & {$[66,67,89]$} & miR-let-7 & Chemoresistance & {$[82,85,95]$} \\
\hline $\operatorname{miR}-183 / 96 / 182$ & Migration & {$[70]$} & miR-34a & $\begin{array}{l}\text { Antiproliferation } \\
\text { Pro-apoptosis } \\
\text { Senescence }\end{array}$ & {$[89,96-99]$} \\
\hline \multirow[t]{7}{*}{$\begin{array}{l}\text { miR-196b-5p, } \\
\text { miR-200b-3p }\end{array}$} & $\begin{array}{l}\text { C-Myc target } \\
\text { Proliferation } \\
\text { Migration } \\
\text { Invasion }\end{array}$ & [100] & $\operatorname{miR}-125 b$ & $\begin{array}{l}\text { Suppressing } \\
\text { progenitor and } \\
\text { tumor cell growth }\end{array}$ & [82] \\
\hline & & & miR-128a & $\begin{array}{l}\text { Antiproliferation } \\
\text { Senescence }\end{array}$ & {$[85,90]$} \\
\hline & & & $\operatorname{miR}-135 a$ & $\begin{array}{l}\text { Reduces } \\
\text { tumorigenicity }\end{array}$ & {$[82,85,101]$} \\
\hline & & & miR-218 & $\begin{array}{l}\text { Antiproliferation. } \\
\text { Reduces } \\
\text { clonogenicity } \\
\text { Promotes } \\
\text { differentiation }\end{array}$ & [102-104] \\
\hline & & & miR-219 & $\begin{array}{l}\text { Antiproliferation } \\
\text { Invasion } \\
\text { Migration } \\
\text { [85,104,105] } \\
\text { (Ferretti et al., 2009, } \\
\text { Genovesi et al., 2011, } \\
\text { Shi et al., 2014) }\end{array}$ & {$[64,101,102]$} \\
\hline & & & $\operatorname{miR}-324-5 p$ & Proliferation & [82] \\
\hline & & & miR-326 & $\begin{array}{c}\text { Reduces } \\
\text { clonogenicity }\end{array}$ & [82] \\
\hline \multicolumn{6}{|c|}{ SUBGROUP 3} \\
\hline \multirow[t]{6}{*}{$\begin{array}{c}\text { miRNAs } \\
\text { as Oncogenes }\end{array}$} & Cellular Function & Ref. & $\begin{array}{l}\text { miRNAs } \\
\text { as Suppressors }\end{array}$ & Cellular Function & Ref. \\
\hline & & & miR-204 & $\begin{array}{c}\text { IGF2R and LC3B } \\
\text { target } \\
\text { Anchorage- } \\
\text { indipendent } \\
\text { growth } \\
\text { Invasion.Autophagy }\end{array}$ & [106] \\
\hline & & & miR-218 & $\begin{array}{l}\text { Antiproliferation. } \\
\text { Reduces } \\
\text { clonogenicity } \\
\text { Promotes } \\
\text { differentiation }\end{array}$ & [102-104] \\
\hline & & & miR-495 & $\begin{array}{l}\text { Gfi1 target } \\
\text { Cell growth } \\
\text { inhibition }\end{array}$ & [107] \\
\hline & & & $\operatorname{miR}-1253$ & $\begin{array}{l}\text { Pro-apoptosis } \\
\text { Antiproliferation }\end{array}$ & [72] \\
\hline & & & $\operatorname{miR}-9$ & $\begin{array}{l}\text { Antiproliferation } \\
\text { Differentiation } \\
\text { Pro-apoptosis }\end{array}$ & {$[85,92]$} \\
\hline
\end{tabular}


Table 1. Cont.

\begin{tabular}{|c|c|c|c|c|c|}
\hline \multicolumn{6}{|c|}{ SUBGROUP 4} \\
\hline \multirow[t]{5}{*}{$\begin{array}{c}\text { miRNAs } \\
\text { as Oncogenes }\end{array}$} & $\begin{array}{l}\text { Cellular } \\
\text { Function }\end{array}$ & Ref. & $\begin{array}{c}\text { miRNAs } \\
\text { as Suppressors }\end{array}$ & Cellular Function & Ref. \\
\hline & & & $\operatorname{miR}-9$ & $\begin{array}{l}\text { Antiproliferation } \\
\text { Differentiation } \\
\text { Pro-apoptosis }\end{array}$ & {$[85,92]$} \\
\hline & & & miR-204 & $\begin{array}{l}\text { IGF2R and LC3B target } \\
\text { Anchorage-independent } \\
\text { growth } \\
\text { Invasion. } \\
\text { Autophagy }\end{array}$ & [106] \\
\hline & & & $\operatorname{miR}-495$ & $\begin{array}{c}\text { Gfi1 target } \\
\text { Cell growth inhibition }\end{array}$ & [107] \\
\hline & & & $\operatorname{miR}-1253$ & $\begin{array}{l}\text { Pro-apoptosis } \\
\text { Antiproliferation }\end{array}$ & [72] \\
\hline \multicolumn{6}{|c|}{ SUBGROUP NOT SPECIFIED } \\
\hline $\begin{array}{l}\text { miRNAs } \\
\text { as Oncogenes }\end{array}$ & $\begin{array}{l}\text { Cellular } \\
\text { Function }\end{array}$ & Ref. & $\begin{array}{l}\text { miRNAs } \\
\text { as Suppressors }\end{array}$ & Cellular Function & Ref. \\
\hline $\operatorname{miR}-21$ & Metastasis & [108] & $\operatorname{miR}-31$ & Antiproliferation & {$[85,109,110]$} \\
\hline $\mathrm{miR}-106 \mathrm{a} / 363$ & $\begin{array}{l}\text { Proliferation } \\
\text { Apoptosis } \\
\text { Angiogenesis }\end{array}$ & [111] & $\operatorname{miR}-124$ & $\begin{array}{l}\text { Differentiation } \\
\text { Antiproliferation } \\
\text { Pro-apoptosis }\end{array}$ & {$[82,112,113]$} \\
\hline miR-106b & $\begin{array}{l}\text { PTEN target } \\
\text { Migration } \\
\text { Invasion } \\
\text { Tumor-sphere } \\
\text { formation }\end{array}$ & [114] & $\operatorname{miR}-125 a$ & Antiproliferation & [85] \\
\hline \multirow[t]{4}{*}{$\operatorname{miR}-367$} & $\begin{array}{l}\text { Invasion } \\
\text { Proliferation }\end{array}$ & [115] & miR-199b-5p & $\begin{array}{c}\text { Antiproliferation } \\
\text { Reduces cancer stem cells }\end{array}$ & {$[91,116]$} \\
\hline & & & miR-206 & Antiproliferation & {$[58,93,117,118]$} \\
\hline & & & $\operatorname{miR}-378$ & $\begin{array}{c}\text { Differentiation } \\
\text { Cell growth inhibition }\end{array}$ & [119] \\
\hline & & & $\operatorname{miR}-383$ & Pro-apoptosis & {$[120,121]$} \\
\hline
\end{tabular}

\section{Clinical Application of miRNAs in Medulloblastoma}

The epigenetic landscape, as well as DNA mutation or miRNAs expression of medulloblastoma, has been investigated for the last 20 years to discover novel biomarkers for diagnosis, treatment, and/or disease progression [122]. miRNAs analysis in medulloblastoma tissue samples, as well as in cerebrospinal fluid (CSF) and in blood has been performed $[14,123]$. Additionally, miRNA expression in extracellular vesicles isolated from CSF or blood has been investigated. Several miRNAs were found differentially expressed between the different MBs subgroups. Gershanov et al. [76], found three miRNAs differentially express in G4-MB. These miRNAs are miR-20a-5p, 181a-2-3p, and 224-5p. Additionally, Li et al. [59] reported that miR-449a is a very good candidate for WNT-MB. However, Yogi et al. [60] reported that miR-148a is a good candidate for WNT-MBs classification. However, due to the significant variation between samples (primary cells, cell lines, patients) and miRNA expression in these studies is making very difficult to select a miRNA or set of miRNAs to improve medulloblastoma diagnosis and treatment. Fortunately, with the onset of new techniques based on the study of miRNAs and the analysis of patients' samples with medulloblastoma, miRNAs could be drastically improved to select aggressive versus non-aggressive medulloblastoma subgroups for treatment selection. Thus, 
considering their important roles in medulloblastoma development, miRNAs have been investigated as prognostic and diagnostic biomarkers for cancer detection, and also as useful targets for therapeutic intervention [124]. miRNA-based therapeutic treatments for medulloblastoma may follow the same strategies described above: miRNA over-expression or miRNA repression. However, the use of miRNAs as potential therapeutic targets for medulloblastoma remains controversial with regard to the ability of the miRNA delivery to pass through the blood-brain barrier. In order to overcome this limit, different systems to transport siRNA into the brain have been developed, such as engineered nanoparticles, vector-based, chemically modified, and "packaged" RNA oligonucleotides [95].

\section{Conclusions}

Medulloblastoma is a tumour of the paediatric population, the second most widespread brain tumour, after astrocytomas, and represents $1 \%$ of all cancers of the CNS [6]. A total of $70 \%$ of medulloblastomas are diagnosed between the second and tenth year of life. Survival five years from diagnosis (children and adults) is just over 60-70\% [125].

Aberrant mechanisms of neuronal and cerebellar development can lead to the formation of medulloblastoma. These genetic and epigenetic changes can cause the abnormal activation of the Hedgehog signal pathway. In recent years, a hierarchical model for the evolution of cancer has been proposed, in which cancer stem cells (CSCs) acquire or maintain the properties of self-renewal, multipotency and tumour generation. This model has also found application in medulloblastoma, as CSCs have been observed in both mice and humans [126]. Furthermore, it was possible to demonstrate the correlation between the Hedgehog signalling pathway and these tumour cells [126], whose presence can lead to greater resistance to classical therapies and probability of relapse.

Most children die within three years due to aggressive treatment or recurrency [27]. Survivors must cope with severe long-term side effects; radiation of the entire developing brain and spinal cord to prevent metastatic recurrence have a devastating effect on intelligence, neurological and endocrine function [27]. Therefore, it is crucial to identify novel and effective therapeutic targets to treat these tumours and improve the quality of life of patients [127].

MiRNAs are known to play vital roles in nervous system development, as well as in various aspects of cancer development, progression, and metastasis. Thus, their involvement in medulloblastoma tumours is not surprising. In this review, we summarized the most important findings present in the literature on the role of miRNAs in influencing the tumorigenesis of medulloblastoma, inducing apoptosis and restoring sensitivity to chemotherapy $[89,91]$. Such as miR-326 that is absent in brain tumour pathologies and is involved in the modulation of signalling pathways, such as Hedgehog and Notch [82,85]. In particular, it interacts with the Hedgehog signalling pathway by negatively modulating the expression of the SMO activating receptor in cerebellar granules [82].

Furthermore, as we have seen, miRNAs are able not only to distinguish normal tissue from tumour, but also to characterize the different subgroups of medulloblastoma. Therefore, they can be used as biomarkers of tumour early diagnosis, prognosis, and provide new opportunities to treat the different clinical and biological features between subgroups.

In conclusion, it is crucial to know the functional and disease-associated mechanisms causing the deregulation of these small RNAs in medulloblastoma. Even though substantial questions must be answered, such as the role of the miRNAs in the development and progression of the different tumoral subgroups, they still represent a suitable target for the future medical treatment of medulloblastoma therapy, able to change the medical practice in the foreseeable future. 
Author Contributions: E.B., J.F., M.V.N.-C. and P.T. wrote the paper. E.B. prepared the figures. M.V.N.-C. and P.T. correct the manuscript. All authors have read and agreed to the published version of the manuscript.

Funding: This work was funded by a Children with Cancer UK fellowship (No. 2014-178), Barts Charity (No. MGU0473), and Life Sciences Institute Fellowship Seed Award-QMUL awarded to M.V.N.-C. and by ERASMUS fellowship to J.F.

Conflicts of Interest: The authors declare no conflict of interest.

\section{References}

1. Packer, R.J.; Vezina, G. Management of and prognosis with medulloblastoma: Therapy at a crossroads. Arch. Neurol. 2008, 65, 1419-1424. [CrossRef] [PubMed]

2. Bondy, M.L.; Scheurer, M.E.; Malmer, B.; Barnholtz-Sloan, J.S.; Davis, F.G.; Il'yasova, D.; Kruchko, C.; McCarthy, B.J.; Rajaraman, P.; Schwartzbaum, J.A.; et al. Brain tumor epidemiology: Consensus from the Brain Tumor Epidemiology Consortium. Cancer 2008, 113, 1953-1968. [CrossRef] [PubMed]

3. Group, A.W.; Busco, S.; Buzzoni, C.; Mallone, S.; Trama, A.; Castaing, M.; Bella, F.; Amodio, R.; Bizzoco, S.; Cassetti, T.; et al. Italian cancer figures-Report 2015: The burden of rare cancers in Italy. Epidemiol. Prev. 2016, 40, 1-120. [CrossRef]

4. Northcott, P.A.; Robinson, G.W.; Kratz, C.P.; Mabbott, D.J.; Pomeroy, S.L.; Clifford, S.C.; Rutkowski, S.; Ellison, D.W.; Malkin, D.; Taylor, M.D.; et al. Medulloblastoma. Nat. Rev. Dis. Primers 2019, 5, 11. [CrossRef] [PubMed]

5. Huang, M.; Tailor, J.; Zhen, Q.; Gillmor, A.H.; Miller, M.L.; Weishaupt, H.; Chen, J.; Zheng, T.; Nash, E.K.; McHenry, L.K.; et al. Engineering Genetic Predisposition in Human Neuroepithelial Stem Cells Recapitulates Medulloblastoma Tumorigenesis. Cell Stem Cell 2019, 25, 433-446.e7. [CrossRef] [PubMed]

6. Quinlan, A.; Rizzolo, D. Understanding medulloblastoma. J. Am. Acad. Phys. Assist. 2017, 30, 30-36. [CrossRef] [PubMed]

7. Wells, E.M.; Packer, R.J. Pediatric brain tumors. Continuum 2015, 21, 373-396. [CrossRef] [PubMed]

8. Waszak, S.M.; Northcott, P.A.; Buchhalter, I.; Robinson, G.W.; Sutter, C.; Groebner, S.; Grund, K.B.; Brugieres, L.; Jones, D.T.W.; Pajtler, K.W.; et al. Spectrum and prevalence of genetic predisposition in medulloblastoma: A retrospective genetic study and prospective validation in a clinical trial cohort. Lancet Oncol. 2018, 19, 785-798. [CrossRef]

9. Kumar, V.; Kumar, V.; McGuire, T.; Coulter, D.W.; Sharp, J.G.; Mahato, R.I. Challenges and Recent Advances in Medulloblastoma Therapy. Trends Pharmacol. Sci. 2017, 38, 1061-1084. [CrossRef] [PubMed]

10. Buruiana, A.; Florian, S.I.; Florian, A.I.; Timis, T.L.; Mihu, C.M.; Miclaus, M.; Osan, S.; Hrapsa, I.; Cataniciu, R.C.; Farcas, M.; et al. The Roles of miRNA in Glioblastoma Tumor Cell Communication: Diplomatic and Aggressive Negotiations. Int. J. Mol. Sci. 2020, 21, 1950. [CrossRef] [PubMed]

11. Archer, T.C.; Mahoney, E.L.; Pomeroy, S.L. Medulloblastoma: Molecular Classification-Based Personal Therapeutics. Neurotherapeutics 2017, 14, 265-273. [CrossRef] [PubMed]

12. Louis, D.N.; Ohgaki, H.; Wiestler, O.D.; Cavenee, W.K.; Burger, P.C.; Jouvet, A.; Scheithauer, B.W.; Kleihues, P. The 2007 WHO classification of tumours of the central nervous system. Acta Neuropathol. 2007, 114, 97-109. [CrossRef] [PubMed]

13. Cavalli, F.M.G.; Remke, M.; Rampasek, L.; Peacock, J.; Shih, D.J.H.; Luu, B.; Garzia, L.; Torchia, J.; Nor, C.; Morrissy, A.S.; et al. Intertumoral Heterogeneity within Medulloblastoma Subgroups. Cancer Cell 2017, 31, 737-754.e6. [CrossRef] [PubMed]

14. Laneve, P.; Caffarelli, E. The Non-coding Side of Medulloblastoma. Front. Cell Dev. Biol. 2020, 8, 275. [CrossRef] [PubMed]

15. Orr, B.A. Pathology, diagnostics, and classification of medulloblastoma. Brain Pathol. 2020, 30, 664-678. [CrossRef] [PubMed]

16. Garzia, L.; Kijima, N.; Morrissy, A.S.; De Antonellis, P.; Guerreiro-Stucklin, A.; Holgado, B.L.; Wu, X.; Wang, X.; Parsons, M.; Zayne, K.; et al. A Hematogenous Route for Medulloblastoma Leptomeningeal Metastases. Cell 2018, 172, 1050-1062.e14. [CrossRef] [PubMed]

17. Khatua, S.; Song, A.; Citla Sridhar, D.; Mack, S.C. Childhood Medulloblastoma: Current Therapies, Emerging Molecular Landscape and Newer Therapeutic Insights. Curr. Neuropharmacol. 2018, 16, 1045-1058. [CrossRef] [PubMed]

18. Gottardo, N.G.; Gajjar, A. Current therapy for medulloblastoma. Curr. Treat. Options Neurol. 2006, 8, 319-334. [CrossRef] [PubMed]

19. Frisira, E.; Rashid, F.; Varma, S.N.; Badodi, S.; Benjamin-Ombo, V.A.; Michod, D.; Niklison-Chirou, M.V. NPI-0052 and gammaradiation induce a synergistic apoptotic effect in medulloblastoma. Cell Death Dis. 2019, 10, 785. [CrossRef]

20. Ashley, D.M.; Merchant, T.E.; Strother, D.; Zhou, T.; Duffner, P.; Burger, P.C.; Miller, D.C.; Lyon, N.; Bonner, M.J.; Msall, M.; et al. Induction chemotherapy and conformal radiation therapy for very young children with nonmetastatic medulloblastoma: Children's Oncology Group study P9934. J. Clin. Oncol. 2012, 30, 3181-3186. [CrossRef]

21. Gupta, T.; Sarkar, C.; Rajshekhar, V.; Chatterjee, S.; Shirsat, N.; Muzumdar, D.; Pungavkar, S.; Chinnaswamy, G.; Jalali, R. Indian Society of Neuro-Oncology consensus guidelines for the contemporary management of medulloblastoma. Neurol. India 2017, 65, 315-332. [CrossRef] [PubMed]

22. Garzon, R.; Calin, G.A.; Croce, C.M. MicroRNAs in Cancer. Annu. Rev. Med. 2009, 60, 167-179. [CrossRef] [PubMed]

23. Vaucheret, H.; Vazquez, F.; Crete, P.; Bartel, D.P. The action of ARGONAUTE1 in the miRNA pathway and its regulation by the miRNA pathway are crucial for plant development. Genes Dev. 2004, 18, 1187-1197. [CrossRef] [PubMed]

24. Esquela-Kerscher, A.; Slack, F.J. Oncomirs-MicroRNAs with a role in cancer. Nat. Rev. Cancer 2006, 6, 259-269. [CrossRef] [PubMed] 
25. Harfe, B.D. MicroRNAs in vertebrate development. Curr. Opin. Genet. Dev. 2005, 15, 410-415. [CrossRef]

26. Fabian, M.R.; Sonenberg, N. The mechanics of miRNA-mediated gene silencing: A look under the hood of miRISC. Nat. Struct. Mol. Biol. 2012, 19, 586-593. [CrossRef] [PubMed]

27. Chen, H.; Shalom-Feuerstein, R.; Riley, J.; Zhang, S.D.; Tucci, P.; Agostini, M.; Aberdam, D.; Knight, R.A.; Genchi, G.; Nicotera, P.; et al. miR-7 and miR-214 are specifically expressed during neuroblastoma differentiation, cortical development and embryonic stem cells differentiation, and control neurite outgrowth in vitro. Biochem. Biophys. Res. Commun. 2010, 394, 921-927. [CrossRef] [PubMed]

28. Feng, W.; Feng, Y. MicroRNAs in neural cell development and brain diseases. Sci. China Life Sci. 2011, 54, 1103-1112. [CrossRef] [PubMed]

29. Bak, M.; Silahtaroglu, A.; Moller, M.; Christensen, M.; Rath, M.F.; Skryabin, B.; Tommerup, N.; Kauppinen, S. MicroRNA expression in the adult mouse central nervous system. RNA 2008, 14, 432-444. [CrossRef]

30. Agostini, M.; Tucci, P.; Killick, R.; Candi, E.; Sayan, B.S.; Rivetti di Val Cervo, P.; Nicotera, P.; McKeon, F.; Knight, R.A.; Mak, T.W.; et al. Neuronal differentiation by TAp73 is mediated by microRNA-34a regulation of synaptic protein targets. Proc. Natl. Acad. Sci. USA 2011, 108, 21093-21098. [CrossRef] [PubMed]

31. Agostini, M.; Tucci, P.; Steinert, J.R.; Shalom-Feuerstein, R.; Rouleau, M.; Aberdam, D.; Forsythe, I.D.; Young, K.W.; Ventura, A.; Concepcion, C.P.; et al. microRNA-34a regulates neurite outgrowth, spinal morphology, and function. Proc. Natl. Acad. Sci. USA 2011, 108, 21099-21104. [CrossRef]

32. Bonev, B.; Pisco, A.; Papalopulu, N. MicroRNA-9 reveals regional diversity of neural progenitors along the anterior-posterior axis. Dev. Cell 2011, 20, 19-32. [CrossRef] [PubMed]

33. Makeyev, E.V.; Zhang, J.; Carrasco, M.A.; Maniatis, T. The MicroRNA miR-124 promotes neuronal differentiation by triggering brain-specific alternative pre-mRNA splicing. Mol. Cell 2007, 27, 435-448. [CrossRef] [PubMed]

34. Titze-de-Almeida, S.S.; Soto-Sanchez, C.; Fernandez, E.; Koprich, J.B.; Brotchie, J.M.; Titze-de-Almeida, R. The Promise and Challenges of Developing miRNA-Based Therapeutics for Parkinson's Disease. Cells 2020, 9, 841. [CrossRef] [PubMed]

35. Gui, Y.; Liu, H.; Zhang, L.; Lv, W.; Hu, X. Altered microRNA profiles in cerebrospinal fluid exosome in Parkinson disease and Alzheimer disease. Oncotarget 2015, 6, 37043-37053. [CrossRef] [PubMed]

36. Bruce, J.P.; Hui, A.B.; Shi, W.; Perez-Ordonez, B.; Weinreb, I.; Xu, W.; Haibe-Kains, B.; Waggott, D.M.; Boutros, P.C.; O’Sullivan, B.; et al. Identification of a microRNA signature associated with risk of distant metastasis in nasopharyngeal carcinoma. Oncotarget 2015, 6, 4537-4550. [CrossRef] [PubMed]

37. Calin, G.A.; Dumitru, C.D.; Shimizu, M.; Bichi, R.; Zupo, S.; Noch, E.; Aldler, H.; Rattan, S.; Keating, M.; Rai, K.; et al. Frequent deletions and down-regulation of micro- RNA genes miR15 and miR16 at 13q14 in chronic lymphocytic leukemia. Proc. Natl. Acad. Sci. USA 2002, 99, 15524-15529. [CrossRef]

38. Mollashahi, B.; Aghamaleki, F.S.; Movafagh, A. The Roles of miRNAs in Medulloblastoma: A Systematic Review. J. Cancer Prev. 2019, 24, 79-90. [CrossRef] [PubMed]

39. Fasoulakis, Z.; Daskalakis, G.; Diakosavvas, M.; Papapanagiotou, I.; Theodora, M.; Bourazan, A.; Alatzidou, D.; Pagkalos, A.; Kontomanolis, E.N. MicroRNAs Determining Carcinogenesis by Regulating Oncogenes and Tumor Suppressor Genes During Cell Cycle. Microrna 2020, 9, 82-92. [CrossRef] [PubMed]

40. Zhang, L.; Huang, J.; Yang, N.; Greshock, J.; Megraw, M.S.; Giannakakis, A.; Liang, S.; Naylor, T.L.; Barchetti, A.; Ward, M.R.; et al. microRNAs exhibit high frequency genomic alterations in human cancer. Proc. Natl. Acad. Sci. USA 2006, 103, 9136-9141. [CrossRef]

41. Lehmann, U.; Hasemeier, B.; Christgen, M.; Muller, M.; Romermann, D.; Langer, F.; Kreipe, H. Epigenetic inactivation of microRNA gene hsa-mir-9-1 in human breast cancer. J. Pathol. 2008, 214, 17-24. [CrossRef]

42. Kano, M.; Seki, N.; Kikkawa, N.; Fujimura, L.; Hoshino, I.; Akutsu, Y.; Chiyomaru, T.; Enokida, H.; Nakagawa, M.; Matsubara, H. miR-145, miR-133a and miR-133b: Tumor-suppressive miRNAs target FSCN1 in esophageal squamous cell carcinoma. Int. J. Cancer 2010, 127, 2804-2814. [CrossRef] [PubMed]

43. Boscaino, V.; Fiannaca, A.; La Paglia, L.; La Rosa, M.; Rizzo, R.; Urso, A. MiRNA therapeutics based on logic circuits of biological pathways. BMC Bioinform. 2019, 20, 344. [CrossRef]

44. Lu, J.; Getz, G.; Miska, E.A.; Alvarez-Saavedra, E.; Lamb, J.; Peck, D.; Sweet-Cordero, A.; Ebert, B.L.; Mak, R.H.; Ferrando, A.A.; et al. MicroRNA expression profiles classify human cancers. Nature 2005, 435, 834-838. [CrossRef]

45. Di Leva, G.; Garofalo, M.; Croce, C.M. MicroRNAs in cancer. Annu. Rev. Pathol. 2014, 9, 287-314. [CrossRef] [PubMed]

46. Cortez, M.A.; Bueso-Ramos, C.; Ferdin, J.; Lopez-Berestein, G.; Sood, A.K.; Calin, G.A. MicroRNAs in body fluids-The mix of hormones and biomarkers. Nat. Rev. Clin. Oncol. 2011, 8, 467-477. [CrossRef]

47. Iorio, M.V.; Croce, C.M. MicroRNAs in cancer: Small molecules with a huge impact. J. Clin. Oncol. 2009, 27, 5848-5856. [CrossRef] [PubMed]

48. Gambari, R.; Brognara, E.; Spandidos, D.A.; Fabbri, E. Targeting oncomiRNAs and mimicking tumor suppressor miRNAs: Nuew trends in the development of miRNA therapeutic strategies in oncology (Review). Int. J. Oncol. 2016, 49, 5-32. [CrossRef] [PubMed]

49. Northcott, P.A.; Shih, D.J.; Peacock, J.; Garzia, L.; Morrissy, A.S.; Zichner, T.; Stutz, A.M.; Korshunov, A.; Reimand, J.; Schumacher, S.E.; et al. Subgroup-specific structural variation across 1,000 medulloblastoma genomes. Nature 2012, $488,49-56$. [CrossRef] [PubMed] 
50. Taylor, M.D.; Northcott, P.A.; Korshunov, A.; Remke, M.; Cho, Y.J.; Clifford, S.C.; Eberhart, C.G.; Parsons, D.W.; Rutkowski, S.; Gajjar, A.; et al. Molecular subgroups of medulloblastoma: The current consensus. Acta Neuropathol. 2012, 123, 465-472. [CrossRef]

51. Ellison, D.W.; Dalton, J.; Kocak, M.; Nicholson, S.L.; Fraga, C.; Neale, G.; Kenney, A.M.; Brat, D.J.; Perry, A.; Yong, W.H.; et al. Medulloblastoma: Clinicopathological correlates of SHH, WNT, and non-SHH/WNT molecular subgroups. Acta Neuropathol. 2011, 121, 381-396. [CrossRef] [PubMed]

52. Goschzik, T.; Zur Muhlen, A.; Kristiansen, G.; Haberler, C.; Stefanits, H.; Friedrich, C.; von Hoff, K.; Rutkowski, S.; Pfister, S.M.; Pietsch, T. Molecular stratification of medulloblastoma: Comparison of histological and genetic methods to detect Wnt activated tumours. Neuropathol. Appl. Neurobiol. 2015, 41, 135-144. [CrossRef] [PubMed]

53. Juraschka, K.; Taylor, M.D. Medulloblastoma in the age of molecular subgroups: A review. J. Neurosurg. Pediatrics 2019, 24, 353-363. [CrossRef]

54. Ramaswamy, V.; Nor, C.; Taylor, M.D. p53 and Meduloblastoma. Cold Spring Harb. Perspect. Med. 2015, 6, a026278. [CrossRef] [PubMed]

55. Phoenix, T.N.; Patmore, D.M.; Boop, S.; Boulos, N.; Jacus, M.O.; Patel, Y.T.; Roussel, M.F.; Finkelstein, D.; Goumnerova, L.; Perreault, S.; et al. Medulloblastoma Genotype Dictates Blood Brain Barrier Phenotype. Cancer Cell 2016, $29,508-522$. [CrossRef] [PubMed]

56. Manoranjan, B.; Venugopal, C.; Bakhshinyan, D.; Adile, A.A.; Richards, L.; Kameda-Smith, M.M.; Whitley, O.; Dvorkin-Gheva, A.; Subapanditha, M.; Savage, N.; et al. Wnt activation as a therapeutic strategy in medulloblastoma. Nat. Commun. 2020, 11, 4323. [CrossRef] [PubMed]

57. Dai, J.; Li, Q.; Bing, Z.; Zhang, Y.; Niu, L.; Yin, H.; Yuan, G.; Pan, Y. Comprehensive analysis of a microRNA expression profile in pediatric medulloblastoma. Mol. Med. Rep. 2017, 15, 4109-4115. [CrossRef] [PubMed]

58. Panwalkar, P.; Moiyadi, A.; Goel, A.; Shetty, P.; Goel, N.; Sridhar, E.; Shirsat, N. MiR-206, a Cerebellum Enriched miRNA Is Downregulated in All Medulloblastoma Subgroups and Its Overexpression Is Necessary for Growth Inhibition of Medulloblastoma Cells. J. Mol. Neurosci. 2015, 56, 673-680. [CrossRef] [PubMed]

59. Li, Y.; Jiang, T.; Shao, L.; Liu, Y.; Zheng, C.; Zhong, Y.; Zhang, J.; Chang, Q. Mir-449a, a potential diagnostic biomarker for WNT group of medulloblastoma. J. Neurooncol. 2016, 129, 423-431. [CrossRef] [PubMed]

60. Yogi, K.; Sridhar, E.; Goel, N.; Jalali, R.; Goel, A.; Moiyadi, A.; Thorat, R.; Panwalkar, P.; Khire, A.; Dasgupta, A.; et al. MiR-148a, a microRNA upregulated in the WNT subgroup tumors, inhibits invasion and tumorigenic potential of medulloblastoma cells by targeting Neuropilin 1. Oncoscience 2015, 2, 334-348. [CrossRef]

61. Kool, M.; Jones, D.T.; Jager, N.; Northcott, P.A.; Pugh, T.J.; Hovestadt, V.; Piro, R.M.; Esparza, L.A.; Markant, S.L.; Remke, M.; et al. Genome sequencing of SHH medulloblastoma predicts genotype-related response to smoothened inhibition. Cancer Cell 2014, 25, 393-405. [CrossRef] [PubMed]

62. Zhukova, N.; Ramaswamy, V.; Remke, M.; Pfaff, E.; Shih, D.J.; Martin, D.C.; Castelo-Branco, P.; Baskin, B.; Ray, P.N.; Bouffet, E.; et al. Subgroup-specific prognostic implications of TP53 mutation in medulloblastoma. J. Clin. Oncol. 2013, 31, $2927-2935$. [CrossRef] [PubMed]

63. Rausch, T.; Jones, D.T.; Zapatka, M.; Stutz, A.M.; Zichner, T.; Weischenfeldt, J.; Jager, N.; Remke, M.; Shih, D.; Northcott, P.A.; et al. Genome sequencing of pediatric medulloblastoma links catastrophic DNA rearrangements with TP53 mutations. Cell 2012, 148, 59-71. [CrossRef] [PubMed]

64. Besharat, Z.M.; Sabato, C.; Po, A.; Gianno, F.; Abballe, L.; Napolitano, M.; Miele, E.; Giangaspero, F.; Vacca, A.; Catanzaro, G.; et al. Low Expression of miR-466f-3p Sustains Epithelial to Mesenchymal Transition in Sonic Hedgehog Medulloblastoma Stem Cells Through Vegfa-Nrp2 Signaling Pathway. Front. Pharmacol. 2018, 9, 1281. [CrossRef]

65. Miele, E.; Po, A.; Begalli, F.; Antonucci, L.; Mastronuzzi, A.; Marras, C.E.; Carai, A.; Cucchi, D.; Abballe, L.; Besharat, Z.M.; et al. beta-arrestin1-mediated acetylation of Gli1 regulates Hedgehog/Gli signaling and modulates self-renewal of SHH medulloblastoma cancer stem cells. BMC Cancer 2017, 17, 488. [CrossRef] [PubMed]

66. Murphy, B.L.; Obad, S.; Bihannic, L.; Ayrault, O.; Zindy, F.; Kauppinen, S.; Roussel, M.F. Silencing of the miR-17 92 cluster family inhibits medulloblastoma progression. Cancer Res. 2013, 73, 7068-7078. [CrossRef] [PubMed]

67. Northcott, P.A.; Fernandez, L.A.; Hagan, J.P.; Ellison, D.W.; Grajkowska, W.; Gillespie, Y.; Grundy, R.; Van Meter, T.; Rutka, J.T.; Croce, C.M.; et al. The miR-17/92 polycistron is up-regulated in sonic hedgehog-driven medulloblastomas and induced by N-myc in sonic hedgehog-treated cerebellar neural precursors. Cancer Res. 2009, 69, 3249-3255. [CrossRef] [PubMed]

68. Tantawy, M.; Elzayat, M.G.; Yehia, D.; Taha, H. Identification of microRNA signature in different pediatric brain tumors. Genet. Mol. Biol. 2018, 41, 27-34. [CrossRef] [PubMed]

69. Pal, R.; Greene, S. microRNA-10b Is Overexpressed and Critical for Cell Survival and Proliferation in Medulloblastoma. PLoS ONE 2015, 10, e0137845. [CrossRef]

70. Weeraratne, S.D.; Amani, V.; Teider, N.; Pierre-Francois, J.; Winter, D.; Kye, M.J.; Sengupta, S.; Archer, T.; Remke, M.; Bai, A.H.; et al. Pleiotropic effects of miR-183 96 182 converge to regulate cell survival, proliferation and migration in medulloblastoma. Acta Neuropathol. 2012, 123, 539-552. [CrossRef]

71. Singh, S.V.; Dakhole, A.N.; Deogharkar, A.; Kazi, S.; Kshirsagar, R.; Goel, A.; Moiyadi, A.; Jalali, R.; Sridhar, E.; Gupta, T.; et al. Restoration of miR-30a expression inhibits growth, tumorigenicity of medulloblastoma cells accompanied by autophagy inhibition. Biochem. Biophys. Res. Commun. 2017, 491, 946-952. [CrossRef] [PubMed] 
72. Kanchan, R.K.; Perumal, N.; Atri, P.; Chirravuri Venkata, R.; Thapa, I.; Klinkebiel, D.L.; Donson, A.M.; Perry, D.; Punsoni, M.; Talmon, G.A.; et al. MiR-1253 exerts tumor-suppressive effects in medulloblastoma via inhibition of CDK6 and CD276 (B7-H3). Brain Pathol. 2020, 30, 732-745. [CrossRef]

73. Glick, D.; Barth, S.; Macleod, K.F. Autophagy: Cellular and molecular mechanisms. J. Pathol. 2010, 221, 3-12. [CrossRef] [PubMed]

74. Senfter, D.; Samadaei, M.; Mader, R.M.; Gojo, J.; Peyrl, A.; Krupitza, G.; Kool, M.; Sill, M.; Haberler, C.; Ricken, G.; et al. High impact of miRNA-4521 on FOXM1 expression in medulloblastoma. Cell Death Dis. 2019, 10, 696. [CrossRef]

75. Kool, M.; Korshunov, A.; Remke, M.; Jones, D.T.; Schlanstein, M.; Northcott, P.A.; Cho, Y.J.; Koster, J.; Schouten-van Meeteren, A.; van Vuurden, D.; et al. Molecular subgroups of medulloblastoma: An international meta-analysis of transcriptome, genetic aberrations, and clinical data of WNT, SHH, Group 3, and Group 4 medulloblastomas. Acta Neuropathol. 2012, 123, $473-484$. [CrossRef] [PubMed]

76. Gershanov, S.; Toledano, H.; Michowiz, S.; Barinfeld, O.; Pinhasov, A.; Goldenberg-Cohen, N.; Salmon-Divon, M. MicroRNA-mRNA expression profiles associated with medulloblastoma subgroup 4. Cancer Manag. Res. 2018, 10, 339352. [CrossRef] [PubMed]

77. Stromecki, M.; Tatari, N.; Morrison, L.C.; Kaur, R.; Zagozewski, J.; Palidwor, G.; Ramaswamy, V.; Skowron, P.; Wolfl, M.; Milde, T.; et al. Characterization of a novel OTX2-driven stem cell program in Group 3 and Group 4 medulloblastoma. Mol. Oncol. 2018, 12, 495-513. [CrossRef] [PubMed]

78. Shi, L.; Cheng, Z.; Zhang, J.; Li, R.; Zhao, P.; Fu, Z.; You, Y. hsa-mir-181a and hsa-mir-181b function as tumor suppressors in human glioma cells. Brain Res. 2008, 1236, 185-193. [CrossRef]

79. Zhao, J.; Lei, T.; Xu, C.; Li, H.; Ma, W.; Yang, Y.; Fan, S.; Liu, Y. MicroRNA-187, down-regulated in clear cell renal cell carcinoma and associated with lower survival, inhibits cell growth and migration though targeting B7-H3. Biochem. Biophys. Res. Commun. 2013, 438, 439-444. [CrossRef]

80. Mulrane, L.; Madden, S.F.; Brennan, D.J.; Gremel, G.; McGee, S.F.; McNally, S.; Martin, F.; Crown, J.P.; Jirstrom, K.; Higgins, D.G.; et al. miR-187 is an independent prognostic factor in breast cancer and confers increased invasive potential in vitro. Clin. Cancer Res. 2012, 18, 6702-6713. [CrossRef]

81. Hovestadt, V.; Jones, D.T.; Picelli, S.; Wang, W.; Kool, M.; Northcott, P.A.; Sultan, M.; Stachurski, K.; Ryzhova, M.; Warnatz, H.J.; et al. Decoding the regulatory landscape of medulloblastoma using DNA methylation sequencing. Nature 2014, 510, 537-541. [CrossRef]

82. Ferretti, E.; De Smaele, E.; Miele, E.; Laneve, P.; Po, A.; Pelloni, M.; Paganelli, A.; Di Marcotullio, L.; Caffarelli, E.; Screpanti, I.; et al. Concerted microRNA control of Hedgehog signalling in cerebellar neuronal progenitor and tumour cells. EMBO J. 2008, 27, 2616-2627. [CrossRef]

83. Tang, B.; Xu, A.; Xu, J.; Huang, H.; Chen, L.; Su, Y.; Zhang, L.; Li, J.; Fan, F.; Deng, J.; et al. MicroRNA-324-5p regulates stemness, pathogenesis and sensitivity to bortezomib in multiple myeloma cells by targeting hedgehog signaling. Int. J. Cancer 2018, 142, 109-120. [CrossRef] [PubMed]

84. De Smaele, E.; Di Marcotullio, L.; Ferretti, E.; Screpanti, I.; Alesse, E.; Gulino, A. Chromosome 17p deletion in human medulloblastoma: A missing checkpoint in the Hedgehog pathway. Cell Cycle 2004, 3, 1263-1266. [CrossRef] [PubMed]

85. Ferretti, E.; De Smaele, E.; Po, A.; Di Marcotullio, L.; Tosi, E.; Espinola, M.S.; Di Rocco, C.; Riccardi, R.; Giangaspero, F.; Farcomeni, A.; et al. MicroRNA profiling in human medulloblastoma. Int. J. Cancer 2009, 124, 568-577. [CrossRef]

86. Uziel, T.; Karginov, F.V.; Xie, S.; Parker, J.S.; Wang, Y.D.; Gajjar, A.; He, L.; Ellison, D.; Gilbertson, R.J.; Hannon, G.; et al. The miR-17 92 cluster collaborates with the Sonic Hedgehog pathway in medulloblastoma. Proc. Natl. Acad. Sci. USA 2009, 106, 2812-2817. [CrossRef]

87. Lu, Y.; Ryan, S.L.; Elliott, D.J.; Bignell, G.R.; Futreal, P.A.; Ellison, D.W.; Bailey, S.; Clifford, S.C. Amplification and overexpression of Hsa-miR-30b, Hsa-miR-30d and KHDRBS3 at 8q24.22-q24.23 in medulloblastoma. PLoS ONE 2009, 4, e6159. [CrossRef] [PubMed]

88. Bai, A.H.; Milde, T.; Remke, M.; Rolli, C.G.; Hielscher, T.; Cho, Y.J.; Kool, M.; Northcott, P.A.; Jugold, M.; Bazhin, A.V.; et al. MicroRNA-182 promotes leptomeningeal spread of non-sonic hedgehog-medulloblastoma. Acta Neuropathol. 2012, 123, 529-538. [CrossRef] [PubMed]

89. Weeraratne, S.D.; Amani, V.; Neiss, A.; Teider, N.; Scott, D.K.; Pomeroy, S.L.; Cho, Y.J. miR-34a confers chemosensitivity through modulation of MAGE-A and p53 in medulloblastoma. Neuro Oncol. 2011, 13, 165-175. [CrossRef] [PubMed]

90. Venkataraman, S.; Alimova, I.; Fan, R.; Harris, P.; Foreman, N.; Vibhakar, R. MicroRNA 128a increases intracellular ROS level by targeting Bmi-1 and inhibits medulloblastoma cancer cell growth by promoting senescence. PLoS ONE 2010, 5, e10748. [CrossRef] [PubMed]

91. Garzia, L.; Andolfo, I.; Cusanelli, E.; Marino, N.; Petrosino, G.; De Martino, D.; Esposito, V.; Galeone, A.; Navas, L.; Esposito, S.; et al. MicroRNA-199b-5p impairs cancer stem cells through negative regulation of HES1 in medulloblastoma. PLoS ONE 2009, 4, e4998. [CrossRef] [PubMed]

92. Fiaschetti, G.; Abela, L.; Nonoguchi, N.; Dubuc, A.M.; Remke, M.; Boro, A.; Grunder, E.; Siler, U.; Ohgaki, H.; Taylor, M.D.; et al. Epigenetic silencing of miRNA-9 is associated with HES1 oncogenic activity and poor prognosis of medulloblastoma. Br. J. Cancer 2014, 110, 636-647. [CrossRef] [PubMed]

93. Gokhale, A.; Kunder, R.; Goel, A.; Sarin, R.; Moiyadi, A.; Shenoy, A.; Mamidipally, C.; Noronha, S.; Kannan, S.; Shirsat, N.V. Distinctive microRNA signature of medulloblastomas associated with the WNT signaling pathway. J. Cancer Res. Ther. 2010, 6, 521-529. [CrossRef] [PubMed] 
94. Lu, S.; Wang, S.; Geng, S.; Ma, S.; Liang, Z.; Jiao, B. Upregulation of microRNA-224 confers a poor prognosis in glioma patients. Clin. Transl. Oncol. 2013, 15, 569-574. [CrossRef] [PubMed]

95. Kim, D.H.; Rossi, J.J. Strategies for silencing human disease using RNA interference. Nat. Rev. Genet. 2007, 8, 173-184. [CrossRef] [PubMed]

96. De Antonellis, P.; Medaglia, C.; Cusanelli, E.; Andolfo, I.; Liguori, L.; De Vita, G.; Carotenuto, M.; Bello, A.; Formiggini, F.; Galeone, A.; et al. MiR-34a targeting of Notch ligand delta-like 1 impairs CD15+/CD133+ tumor-propagating cells and supports neural differentiation in medulloblastoma. PLoS ONE 2011, 6, e24584. [CrossRef] [PubMed]

97. Morrissy, A.S.; Garzia, L.; Shih, D.J.; Zuyderduyn, S.; Huang, X.; Skowron, P.; Remke, M.; Cavalli, F.M.; Ramaswamy, V.; Lindsay, P.E.; et al. Divergent clonal selection dominates medulloblastoma at recurrence. Nature 2016, 529, 351-357. [CrossRef] [PubMed]

98. Fan, Y.N.; Meley, D.; Pizer, B.; See, V. Mir-34a mimics are potential therapeutic agents for p53-mutated and chemo-resistant brain tumour cells. PLoS ONE 2014, 9, e108514. [CrossRef]

99. Thor, T.; Kunkele, A.; Pajtler, K.W.; Wefers, A.K.; Stephan, H.; Mestdagh, P.; Heukamp, L.; Hartmann, W.; Vandesompele, J.; Sadowski, N.; et al. MiR-34a deficiency accelerates medulloblastoma formation in vivo. Int. J. Cancer 2015, 136, 2293-2303. [CrossRef] [PubMed]

100. Visani, M.; Marucci, G.; Biase, D.; Giangaspero, F.; Buttarelli, F.R.; Brandes, A.A.; Franceschi, E.; Acquaviva, G.; Ciarrocchi, A.; Rhoden, K.J.; et al. miR-196B-5P and miR-200B-3P Are Differentially Expressed in Medulloblastomas of Adults and Children. Diagnostics 2020, 10, 265. [CrossRef] [PubMed]

101. Hemmesi, K.; Squadrito, M.L.; Mestdagh, P.; Conti, V.; Cominelli, M.; Piras, I.S.; Sergi, L.S.; Piccinin, S.; Maestro, R.; Poliani, P.L.; et al. miR-135a Inhibits Cancer Stem Cell-Driven Medulloblastoma Development by Directly Repressing Arhgef6 Expression. Stem Cells 2015, 33, 1377-1389. [CrossRef] [PubMed]

102. Venkataraman, S.; Birks, D.K.; Balakrishnan, I.; Alimova, I.; Harris, P.S.; Patel, P.R.; Handler, M.H.; Dubuc, A.; Taylor, M.D.; Foreman, N.K.; et al. MicroRNA 218 acts as a tumor suppressor by targeting multiple cancer phenotype-associated genes in medulloblastoma. J. Biol. Chem. 2013, 288, 1918-1928. [CrossRef] [PubMed]

103. Shi, J.; Yang, L.; Wang, T.; Zhang, J.; Guo, X.; Huo, X.; Niu, H. miR-218 is downregulated and directly targets SH3GL1 in childhood medulloblastoma. Mol. Med. Rep. 2013, 8, 1111-1117. [CrossRef] [PubMed]

104. Shi, J.A.; Lu, D.L.; Huang, X.; Tan, W. miR-219 inhibits the proliferation, migration and invasion of medulloblastoma cells by targeting CD164. Int. J. Mol. Med. 2014, 34, 237-243. [CrossRef] [PubMed]

105. Genovesi, L.A.; Carter, K.W.; Gottardo, N.G.; Giles, K.M.; Dallas, P.B. Integrated analysis of miRNA and mRNA expression in childhood medulloblastoma compared with neural stem cells. PLoS ONE 2011, 6, e23935. [CrossRef]

106. Bharambe, H.S.; Paul, R.; Panwalkar, P.; Jalali, R.; Sridhar, E.; Gupta, T.; Moiyadi, A.; Shetty, P.; Kazi, S.; Deogharkar, A.; et al. Downregulation of miR-204 expression defines a highly aggressive subset of Group 3/Group 4 medulloblastomas. Acta Neuropathol. Commun. 2019, 7, 52. [CrossRef] [PubMed]

107. Wang, C.; Yun, Z.; Zhao, T.; Liu, X.; Ma, X. MiR-495 is a Predictive Biomarker that Downregulates GFI1 Expression in Medulloblastoma. Cell Physiol. Biochem. 2015, 36, 1430-1439. [CrossRef] [PubMed]

108. Grunder, E.; D’Ambrosio, R.; Fiaschetti, G.; Abela, L.; Arcaro, A.; Zuzak, T.; Ohgaki, H.; Lv, S.Q.; Shalaby, T.; Grotzer, M. MicroRNA-21 suppression impedes medulloblastoma cell migration. Eur. J. Cancer 2011, 47, 2479-2490. [CrossRef]

109. Jin, Y.; Xiong, A.; Zhang, Z.; Li, S.; Huang, H.; Yu, T.T.; Cao, X.; Cheng, S.Y. MicroRNA-31 suppresses medulloblastoma cell growth by inhibiting DNA replication through minichromosome maintenance 2. Oncotarget 2014, 5, 4821-4833. [CrossRef] [PubMed]

110. Ma, H.; Cao, W.; Ding, M. MicroRNA-31 weakens cisplatin resistance of medulloblastoma cells via NF-kappaB and PI3K/AKT pathways. Biofactors 2020, 46, 831-838. [CrossRef] [PubMed]

111. Gruszka, R.; Zakrzewski, K.; Liberski, P.P.; Zakrzewska, M. mRNA and miRNA Expression Analyses of the MYC/E2F/miR-17-92 Network in the Most Common Pediatric Brain Tumors. Int. J. Mol. Sci. 2021, 22, 543. [CrossRef] [PubMed]

112. Pierson, J.; Hostager, B.; Fan, R.; Vibhakar, R. Regulation of cyclin dependent kinase 6 by microRNA 124 in medulloblastoma. J. Neurooncol. 2008, 90, 1-7. [CrossRef] [PubMed]

113. Silber, J.; Hashizume, R.; Felix, T.; Hariono, S.; Yu, M.; Berger, M.S.; Huse, J.T.; VandenBerg, S.R.; James, C.D.; Hodgson, J.G.; et al. Expression of miR-124 inhibits growth of medulloblastoma cells. Neuro Oncol. 2013, 15, 83-90. [CrossRef]

114. Li, K.K.; Xia, T.; Ma, F.M.; Zhang, R.; Mao, Y.; Wang, Y.; Zhou, L.; Lau, K.M.; Ng, H.K. miR-106b is overexpressed in medulloblastomas and interacts directly with PTEN. Neuropathol. Appl. Neurobiol. 2015, 41, 145-164. [CrossRef] [PubMed]

115. Kaid, C.; Silva, P.B.; Cortez, B.A.; Rodini, C.O.; Semedo-Kuriki, P.; Okamoto, O.K. miR-367 promotes proliferation and stem-like traits in medulloblastoma cells. Cancer Sci. 2015, 106, 1188-1195. [CrossRef] [PubMed]

116. Andolfo, I.; Liguori, L.; De Antonellis, P.; Cusanelli, E.; Marinaro, F.; Pistollato, F.; Garzia, L.; De Vita, G.; Petrosino, G.; Accordi, B.; et al. The micro-RNA 199b-5p regulatory circuit involves Hes1, CD15, and epigenetic modifications in medulloblastoma. Neuro Oncol. 2012, 14, 596-612. [CrossRef] [PubMed]

117. Kunder, R.; Jalali, R.; Sridhar, E.; Moiyadi, A.; Goel, N.; Goel, A.; Gupta, T.; Krishnatry, R.; Kannan, S.; Kurkure, P.; et al. Real-time PCR assay based on the differential expression of microRNAs and protein-coding genes for molecular classification of formalin-fixed paraffin embedded medulloblastomas. Neuro Oncol. 2013, 15, 1644-1651. [CrossRef]

118. Pan, X.; Wang, Z.; Wan, B.; Zheng, Z. MicroRNA-206 inhibits the viability and migration of medulloblastoma cells by targeting LIM and SH3 protein 1. Exp. Ther. Med. 2017, 14, 3894-3900. [CrossRef] [PubMed] 
119. Zhang, Z.Y.; Zhu, B.; Zhao, X.W.; Zhan, Y.B.; Bao, J.J.; Zhou, J.Q.; Zhang, F.J.; Yu, B.; Liu, J.; Wang, Y.M.; et al. Regulation of UHRF1 by microRNA-378 modulates medulloblastoma cell proliferation and apoptosis. Oncol. Rep. 2017, 38, 3078-3084. [CrossRef] [PubMed]

120. Li, K.K.; Pang, J.C.; Lau, K.M.; Zhou, L.; Mao, Y.; Wang, Y.; Poon, W.S.; Ng, H.K. MiR-383 is downregulated in medulloblastoma and targets peroxiredoxin 3 (PRDX3). Brain Pathol. 2013, 23, 413-425. [CrossRef] [PubMed]

121. Cui, Y.; Chen, L.G.; Yao, H.B.; Zhang, J.; Ding, K.F. Upregulation of microRNA-383 inhibits the proliferation, migration and invasion of colon cancer cells. Oncol Lett. 2018, 15, 1184-1190. [CrossRef] [PubMed]

122. Pickles, J.C.; Fairchild, A.R.; Stone, T.J.; Brownlee, L.; Merve, A.; Yasin, S.A.; Avery, A.; Ahmed, S.W.; Ogunbiyi, O.; Gonzalez Zapata, J.; et al. DNA methylation-based profiling for paediatric CNS tumour diagnosis and treatment: A population-based study. Lancet Child. Adolesc. Health 2020, 4, 121-130. [CrossRef]

123. Shalaby, T.; Grotzer, M.A. Tumor-Associated CSF MicroRNAs for the Prediction and Evaluation of CNS Malignancies. Int. J. Mol. Sci. 2015, 16, 29103-29119. [CrossRef] [PubMed]

124. Wang, X.; Holgado, B.L.; Ramaswamy, V.; Mack, S.; Zayne, K.; Remke, M.; Wu, X.; Garzia, L.; Daniels, C.; Kenney, A.M.; et al. miR miR on the wall, who's the most malignant medulloblastoma miR of them all? Neuro Oncol. 2018, 20, 313-323. [CrossRef] [PubMed]

125. Shih, D.J.; Northcott, P.A.; Remke, M.; Korshunov, A.; Ramaswamy, V.; Kool, M.; Luu, B.; Yao, Y.; Wang, X.; Dubuc, A.M.; et al. Cytogenetic prognostication within medulloblastoma subgroups. J. Clin. Oncol. 2014, 32, 886-896. [CrossRef] [PubMed]

126. Po, A.; Ferretti, E.; Miele, E.; De Smaele, E.; Paganelli, A.; Canettieri, G.; Coni, S.; Di Marcotullio, L.; Biffoni, M.; Massimi, L.; et al. Hedgehog controls neural stem cells through p53-independent regulation of Nanog. EMBO J. 2010, 29, $2646-2658$. [CrossRef] [PubMed]

127. Niklison-Chirou, M.V.; Erngren, I.; Engskog, M.; Haglof, J.; Picard, D.; Remke, M.; McPolin, P.H.R.; Selby, M.; Williamson, D.; Clifford, S.C.; et al. TAp73 is a marker of glutamine addiction in medulloblastoma. Genes Dev. 2017, 31, 1738-1753. [CrossRef] [PubMed] 